\title{
T45G and G276T Adiponectin Gene Polymorphisms in Primary Aldosteronism and Healthy Controls in an East Slovak Population
}

\author{
I. JOCHMANOVÁ ${ }^{1}$, V. HABALOVÁ ${ }^{2}$, H. WAGNEROVÁ ${ }^{1}$, A. GALOVIČOVÁ ${ }^{1}$, \\ I. LAZÚROVÁ ${ }^{1}$
}

${ }^{1}$ First Department of Internal Medicine, Medical Faculty, P. J. Šafárik University Košice, Slovakia, ${ }^{2}$ Department of Medical Biology, Medical Faculty, P. J. Šafárik University Košice, Slovakia

Received August 21, 2012

Accepted February 21, 2013

On-line April 16, 2013

\section{Summary}

Metabolic complications are frequent in primary aldosteronism (PA) and adiponectin gene polymorphisms seem to confer a genetic risk for metabolic alterations. Aim of the study was to evaluate the prevalence of metabolic symptoms in patients with PA compared to controls and the prevalence of two single nucleotide polymorphisms (SNPs), T45G and G276T, in the adiponectin gene and their relationship to metabolic syndrome (MS). The study involved 47 patients with PA and 90 controls selected from general population. Body mass index (BMI), and selected biochemical parametres were examined, and the mentioned SNPs were genotyped in all subjects. PA patients had a significantly higher BMI $(p<0.0001)$, blood glucose level $(p<0.01)$, and triglycerides $(p<0.0005)$ compared to controls. There were no significant differences in the prevalence of the studied genotypes of adiponectin gene polymorphisms. The 276GT genotype was linked with lower levels of triglycerides $(p \leq 0.05)$, while 276GG was related to higher levels of triglycerides $(p=0.01)$. A similar but nonsignificant tendency was observed in relation to cholesterol levels. We can conclude that PA patients with the 276GT genotype have lower triglycerides levels, but there are not significant differences in the distribution of genotypes and alleles among PA patients and controls in an East Slovak population.

\section{Key words}

Primary aldosteronism - Adiponectine gene polymorphism • Metabolic syndrome $\bullet$ Triglycerides

\section{Corresponding author}

I. Lazúrová, First Department of Internal Medicine, Medical Faculty, P. J. Šafárik University Košice, Trieda SNP 1, 04011 Košice, Slovakia. E-mail: ivica.lazurova@upjs.sk

\section{Introduction}

Metabolic abnormalities, such as alterations in glucose homeostasis, dyslipidemia and obesity, are very common clinical features in patients with essential hypertension (Cuspidi et al. 2004). Previous studies confirmed that they are also associated with primary aldosteronism (PA), the most common form of secondary hypertension (Rossi 2010, for review, see Boscaro et al. 2008), with the prevalence of 5 to $10 \%$ in hypertensive patients (Hannemann and Wallaschofski 2012).

Aldosterone excess is crucial for the development of cardiac and metabolic complications. Many authors documented a higher prevalence of metabolic symptoms in patients with PA compared to those with essential hypertension (EH) (Fallo et al. 2006, Iacobellis et al. 2010, Ronconi et al. 2010).

Adipose tissue secretes a number of adipocytokines, which can be involved in the etiology of obesity and MS (Ehrhart-Bornstein et al. 2004, Inadera 2008). The most studied adipocytokine is adiponectin, a protein with generally positive metabolic effects. It exerts insulin sensitising, anti-inflammatory, and anti-apoptotic actions in cells (Ohashi et al. 2012, Turer and Scherer 2012) and low plasma levels of circulating adiponectin are considered a biomarker of metabolic syndrome (Weyer et al. 2001, Li et al. 2009).

Adiponectin is an $18.5 \mathrm{~kb}$ protein encoded by the ADIPOQ gene located on chromosome 3 q27 consisting of 3 exons. To date, several studies reported association of various single nucleotide polymorphisms (SNPs) in the ADIPOQ gene with MS, obesity, and glucose metabolism 
disorders (Schwarz et al. 2006, Menzaghi et al. 2007, Mtiraoui et al. 2012). Two of the most commonly studied SNPs in the ADIPOQ gene are a silent $T$ to $G$ substitution in exon 2 (T45G, rs2241766) and a $\mathrm{G}$ to $\mathrm{T}$ substitution in intron 2 (G276T, rs1501299). In the T45G SNP, the G allele is associated with several negative effects that include lower adiponectin levels, higher BMI, lower insulin sensitivity, higher risk for developing hyperglycemia and T2DM, and higher levels of blood lipids. Therefore, the $\mathrm{T}$ allele seems to have a protective function for its carriers (reviewed by Enns et al. 2011). The G allele of G276T SNP was reported to be associated with lower insulin sensitivity, increased risk of T2DM, higher levels of blood lipids, and lower levels of circulating adiponectin (Hara et al. 2002, GonzalezSanchez et al. 2005, Huang et al. 2010). Reports on the significance of the $\mathrm{T}$ allele of SNP G276T are controversial, some authors demonstrated its association with higher levels of circulating adiponectin (Menzaghi et al. 2004, Kyriakou et al. 2008), while others documented its association with obesity and lower adiponectin levels (Mousavinasab et al. 2006). There are only poor data regarding the association of these polymorphisms in PA, which is also associated with MS. To the best of our knowledge the only study by Ronconi et al. (2010) aimed at establishing a relationship between adiponectin gene polymorphisms and MS in PA patients. They observed an association of the 276TT genotype of the adiponectin gene with worse metabolic profile in $\mathrm{PA}$ and $\mathrm{EH}$ patients and the $45 \mathrm{GG}+\mathrm{GT}$ genotypes of the adiponectin gene seemed to have a protective role for metabolic complications.

The aims of the present study were to evaluate the prevalence of metabolic symptoms in patients with PA compared to controls selected from general population from Eastern Slovakia and to examine whether there is a higher prevalence of mutant genotypes of two common SNPs (T45G and G276T) of the ADIPOQ gene in patients with PA and metabolic complications. We presume the higher prevalence of metabolic complications in PA patients compared to controls and that there is a relationship between metabolic disturbances in PA patients and the mutant genotypes of studied gene polymorphisms.

\section{Subjects and Methods}

137 subjects living in the same geographic area, the East Slovak region, were genotyped. The first group consisted of 47 unrelated adults with a diagnosis of PA (27 males, 20 females) of mean age $58 \pm 9$ years (range 3276 , median 59). The second group comprised 90 unrelated ethnically matched subjects who were randomly selected from community volunteers in the same district (32 males, 58 females) of mean age $55 \pm 15$, (range 31-81, median 57.5 years). In controls we ruled out only PA diagnosis. All study participants gave separate written consent for the study and the collection of DNA.

Diagnosis of PA was established in all patients by laboratory evaluations including aldosterone renin ratio (ARR, $>40 \mathrm{ng} / \mathrm{dl}$ per $\mathrm{ng} / \mathrm{ml} / \mathrm{h}$ ), lack of supressibility of plasma aldosterone after saline infusion (plasma aldosterone $>7 \mathrm{ng} / \mathrm{dl}$ after saline infusion). Adrenal venous sampling was used for detection of side lateralization in all patients older than 40 years and those under 40 years with negative CT scan (Funder et al. 2008).

Among 47 patients with PA 21 (54 \pm 8.5 years, range 32-66, median 54 years) were diagnosed to have aldosterone producing adenoma (APA) and 26 (62 \pm 8.1 years, range 41-76, median 64 years) had idiopathic aldosteronism (IHA).

All PA patients were treated with spironolactone before surgery. $30(59.57 \%)$ patients were diagnosed with the MS, $13(6.11 \%)$ had T2DM. In the control group $8(8.89 \%)$ subjects fulfilled criteria of MS, the other $11(9.9 \%)$ subjects had dyslipidemia, and 23 (20.7\%) subjects were treated for hypertension. Diet and statins were used for the treatment of lipid metabolism disorder in both groups. Medical treatment of hypertension most frequently included ACE inhibitors, beta and alpha-blockers, and diuretics, respectively.

MS was diagnosed based on Adult Treatment Panel III criteria (Executive summary 2001) requiring the presence of at least 3 of the following abnormalities: waist circumference greater than $88 \mathrm{~cm}$ in women and greater than $102 \mathrm{~cm}$ in men; fasting plasma glucose $\geq 110 \mathrm{mg} / \mathrm{dl}$ (6.1 mmol/l); fasting plasma TGs $\geq 150 \mathrm{mg} / \mathrm{dl}$ (1.69 mmol/l); HDL cholesterol $<40 \mathrm{mg} / \mathrm{dl}$ in men and $<50 \mathrm{mg} / \mathrm{dl}$ (1.29 mmol/l) in women; and blood pressure $\geq 130 / 85 \mathrm{~mm} \mathrm{Hg}$. The diagnosis of MS was postulated retrospectively based on previous data from documentation in each subject included in the study.

Body mass index (BMI), blood glucose, total cholesterol, and triglycerides (TG) levels were examined in all subjects. These parameters were evaluated using routine biochemical methods: plasma renin activity and plasma aldosterone were examined by the RIA method using kits from Immunotech France. 


\section{Genotyping}

Genomic DNA was extracted from lymphocytes using a Wizard Genomic DNA Extraction Kit (Promega), and was resuspended in water to the bring concentration to approximately $20 \mathrm{ng} / \mu \mathrm{l}$. Recently a rapid and unexpansive closed tube assay using small amplicon melting analysis after real-time polymerase chain reaction was described. This approach was adapted for genotyping T45G and G276T single nucleotide polymorphisms in the adiponectin gene in our laboratory. Heterozygotes were identified by a change in melting curve shape, and different homozygotes were distinguished by a change in melting temperature. The PCR was performed in glass capillaries on a LightScanner32 instrument (Idaho Technology Inc. Salt Lake City, USA) in a $15 \mu 1$ reaction volume. Master mix contained: $1 x$ BioTherm $A^{\mathrm{TM}}{ }^{\mathrm{T}}$ buffer (GeneCraft, Munster, Germany), 1x LCGreen ${ }^{\text {Plus }}{ }^{+}$(Idaho Technology Inc.), $250 \mu \mathrm{M}$ dNTP (Jena Bioscience, Jena, Germany), $0.6 \mu \mathrm{M}$ forward primer, $0.6 \mu \mathrm{M}$ reverse primer, $3 \mathrm{mM} \mathrm{MgCl}_{2}$ (Idaho Technology Inc.), $250 \mu \mathrm{g} / \mathrm{ml}$ BSA (Fermentas, Burlington, Canada), 1U BioThermAB ${ }^{\mathrm{TM}}$ polymerase (GeneCraft) and approx. $20 \mathrm{ng}$ DNA. For the SNP T45G, a 50 bp DNA fragment was amplified using the forward primer 5'-GCTGTTCTACTGCTATTAGCTC-3' and reverse primer 5'-GTCGTGGTTTCCTGGTCA-3'. For the G276T SNP, a 71 bp DNA fragment was amplified using the forward primer 5'-CTTTCATCACAGACCTCCTACACÁGA-3' and reverse primer 5'-GTGTCTAGGCCTTAGTTAATAAT GAATG-3'. The mismatch in the forward primer for SNP G276T was introduced to cover another polymorphism in the amplicon that could interfere with the melting analysis. The PCR conditions were as follows: initial denaturation at $95{ }^{\circ} \mathrm{C}$ for $5 \mathrm{~min}, 60$ cycles at $95{ }^{\circ} \mathrm{C}$ for $10 \mathrm{~s}, 54{ }^{\circ} \mathrm{C}$ for $20 \mathrm{~s}$ and $72{ }^{\circ} \mathrm{C}$ for $20 \mathrm{~s}$. Amplification was immediately followed by melting analysis with a denaturation at $95{ }^{\circ} \mathrm{C}$ for $1 \mathrm{~min}$ and renaturation at $40{ }^{\circ} \mathrm{C}$ for $1 \mathrm{~min}$. Data were acquired over the $65-90{ }^{\circ} \mathrm{C}$ range at a thermal transition rate of $0.05{ }^{\circ} \mathrm{C} / \mathrm{s}$.

\section{Statistical analysis}

Data are expressed as mean \pm SD (standard deviation). The central tendencies of the different groups were compared by unpaired two-tailed Student t-test or Mann-Whitney test for non-normally distributed parameters. To compare discrete variables, the $\chi^{2}$ test and Fisher exact test were used as appropriate. The frequencies of the alleles and genotypes in case patients
Table 1. Clinical and biochemical characteristics in controls and PA patients.

\begin{tabular}{|c|c|c|c|}
\hline & $\begin{array}{c}\text { PA } \\
(n=47)\end{array}$ & $\begin{array}{l}\text { Controls } \\
(n=90)\end{array}$ & Significance \\
\hline $\operatorname{Sex}(M / F)$ & $27 / 20$ & $32 / 58$ & \\
\hline Age (years) & $58 \pm 9$ & $55 \pm 15$ & $\mathrm{~ns}$ \\
\hline$B M I\left(\mathrm{~kg} / \mathrm{m}^{2}\right)$ & $29.86 \pm 4.57$ & $25.76 \pm 4.47$ & 0.0001 \\
\hline $\begin{array}{l}\text { Glucose } \\
\text { (mmol/l, 3.0-6.1) }\end{array}$ & $5.32 \pm 1.48$ & $4.84 \pm 0.90$ & 0.010 \\
\hline $\begin{array}{l}\text { Cholesterol } \\
(\mathrm{mmol} / \mathrm{l}, 2.57-5.2)\end{array}$ & $4.68 \pm 0.93$ & $4.89 \pm 1.08$ & ns \\
\hline $\begin{array}{l}\text { Triglycerides } \\
\text { (mmol/l, 0.45-1.75) }\end{array}$ & $1.54 \pm 0.95$ & $1.16 \pm 0.47$ & 0.0005 \\
\hline
\end{tabular}

Table 2. Genotypes and alleles frequencies in PA patients and controls.

\begin{tabular}{|c|c|c|c|}
\hline & $\begin{array}{c}\text { PA } \\
(n=47)\end{array}$ & $\begin{array}{c}\text { Controls } \\
(n=90)\end{array}$ & Significance \\
\hline \multicolumn{4}{|l|}{$T 45 G$} \\
\hline Talleles & $88(94 \%)$ & $157(87 \%)$ & \\
\hline$G$ alleles & $6(6 \%)$ & $23(13 \%)$ & $\mathrm{ns}$ \\
\hline$T T$ & $41(87.23 \%)$ & $69(76.67 \%)$ & ns \\
\hline$T G$ & $6(12.77 \%)$ & $19(21.11 \%)$ & ns \\
\hline$G G$ & $0(0.00 \%)$ & $2(2.22 \%)$ & ns \\
\hline \multicolumn{4}{|l|}{ Hardy- } \\
\hline $\begin{array}{l}\text { Weinberg } \\
\text { equilibrium }\end{array}$ & 0.64 & 0.62 & \\
\hline \multicolumn{4}{|l|}{$G 276 T$} \\
\hline$G$ alleles & $64(68 \%)$ & $129(72 \%)$ & \\
\hline Talleles & $30(32 \%)$ & $51(28 \%)$ & $\mathrm{ns}$ \\
\hline$G G$ & $21(44.68 \%)$ & $45(50.00 \%)$ & ns \\
\hline$G T$ & $22(46.81 \%)$ & $39(43.33 \%)$ & $\mathrm{ns}$ \\
\hline$T T$ & $4(8.51 \%)$ & $6(6.67 \%)$ & ns \\
\hline \multicolumn{4}{|l|}{ Hardy- } \\
\hline $\begin{array}{l}\text { Weinberg } \\
\text { equilibrium }\end{array}$ & 0.597 & 0.525 & \\
\hline
\end{tabular}

and controls were determined by direct count and compared by the $\chi^{2}$ test with the values predicted assuming Hardy-Weinberg equilibrium. A p-value of less than 0.05 indicated statistical significance. The differences between continuous parameters divided into more than two subgroups were tested using one way ANOVA. Log transformation was performed for data 
Table 3. Biochemical and clinical characteristics depending on T45G and G276T gene polymorphisms in PA patients and controls.

\begin{tabular}{|c|c|c|c|c|c|c|c|}
\hline & $45 \mathrm{TT}$ & 45TG+GG & Significance & 276GG & 276GT & 276TT & Significance \\
\hline Patients & $(n=41)$ & $(n=6)$ & & $(n=21)$ & $(n=22)$ & $(n=4)$ & \\
\hline$B M I, \mathrm{~kg} / \mathrm{m}^{2}$ & $30.08 \pm 4.55$ & $28.30 \pm 4.81$ & $\mathrm{~ns}$ & $31.12 \pm 4.72$ & $28.88 \pm 4.41$ & $28.55 \pm 3.80$ & $\mathrm{~ns}$ \\
\hline Glucose & $5.39 \pm 1.56$ & $4.88 \pm 0.55$ & $\mathrm{~ns}$ & $4.96 \pm 0.64$ & $5.64 \pm 2.04$ & $5.47 \pm 0.39$ & ns \\
\hline Cholesterol & $4.60 \pm 0.86$ & $5.25 \pm 1.22$ & $\mathrm{~ns}$ & $4.81 \pm 1.04$ & $4.57 \pm 0.86$ & $4.66 \pm 0.76$ & ns \\
\hline Triglycerides & $1.56 \pm 1.00$ & $1.44 \pm 0.37$ & ns & $1.74 \pm 1.23$ & $1.28 \pm 0.49$ & $1.92 \pm 0.96$ & ns \\
\hline Controls & $(n=69)$ & $(n=21)$ & & $(n=45)$ & $(n=39)$ & $(n=6)$ & \\
\hline$B M I, \mathrm{~kg} / \mathrm{m}^{2}$ & $25.68 \pm 5.00$ & $26.03 \pm 3.46$ & ns & $25.60 \pm 4.14$ & $26.04 \pm 5.36$ & $25.14 \pm 4.22$ & ns \\
\hline Glucose & $4.80 \pm 0.86$ & $5.00 \pm 1.03$ & $\mathrm{~ns}$ & $4.84 \pm 0.98$ & $4.84 \pm 0.81$ & $4.95 \pm 1.04$ & ns \\
\hline Cholesterol & $4.88 \pm 1.08$ & $4.95 \pm 1.08$ & $\mathrm{~ns}$ & $4.93 \pm 1.12$ & $4.93 \pm 1.08$ & $4.39 \pm 0.82$ & ns \\
\hline Triglycerides & $1.16 \pm 0.48$ & $1.18 \pm 0.44$ & $\mathrm{~ns}$ & $1.23 \pm 0.51$ & $1.12 \pm 0.44$ & $0.93 \pm 0.24$ & ns \\
\hline
\end{tabular}

Table 4. Genotypes and alleles frequencies depending on BMI value in controls and PA patients.

\begin{tabular}{|c|c|c|c|c|c|c|c|c|}
\hline & $\begin{array}{l}\text { Patients } \\
\text { BMI } \leq 25 \\
(n=8)\end{array}$ & $\begin{array}{l}\text { BMI } \\
25.1-29.9 \\
(n=15)\end{array}$ & $\begin{array}{l}\text { BMI }>30 \\
(n=22)\end{array}$ & Significance & $\begin{array}{c}\text { Controls } \\
\text { BMI } \leq 25 \\
(n=52)\end{array}$ & $\begin{array}{l}\text { BMI } \\
25.1-29.9 \\
(n=37)\end{array}$ & $\begin{array}{l}\text { BMI }>30 \\
(n=7)\end{array}$ & Significance \\
\hline \multicolumn{9}{|l|}{$T 45 G$} \\
\hline$T$ alleles & $14(88 \%)$ & $28(93 \%)$ & $42(95 \%)$ & & $91(88 \%)$ & $63(85 \%)$ & $13(93 \%)$ & \\
\hline$G$ alleles & $2(12 \%)$ & $2(7 \%)$ & $2(5 \%)$ & ns & $13(12 \%)$ & $11(15 \%)$ & $1(7 \%)$ & $\mathrm{ns}$ \\
\hline$T T$ & $6(75 \%)$ & $13(86.67 \%)$ & $20(90.91 \%)$ & ns & $42(80.77 \%)$ & $26(70.27 \%)$ & $6(85.71 \%)$ & ns \\
\hline$T G+G G$ & $2(25 \%)$ & $2(13.33 \%)$ & $2(9.09 \%)$ & ns & $10(19.23 \%)$ & $11(29.73 \%)$ & $1(14.29 \%)$ & $\mathrm{ns}$ \\
\hline \multicolumn{9}{|l|}{$G 276 T$} \\
\hline$G$ alleles & $9(56 \%)$ & $19(63 \%)$ & $32(73 \%)$ & & $75(72 \%)$ & $51(69 \%)$ & $10(71 \%)$ & \\
\hline T alleles & $7(44 \%)$ & $11(37 \%)$ & $12(27 \%)$ & ns & $29(28 \%)$ & $23(31 \%)$ & $4(29 \%)$ & ns \\
\hline$G G$ & $2(25 \%)$ & $5(33.33 \%)$ & $12(54.55 \%)$ & $\mathrm{ns}$ & $28(53.85 \%)$ & $18(48.65 \%)$ & $3(42.86 \%)$ & $\mathrm{ns}$ \\
\hline$G T$ & $5(62.50 \%)$ & $9(60.00 \%)$ & $8(36.36 \%)$ & $\mathrm{ns}$ & $19(36.54 \%)$ & $15(40.54 \%)$ & $4(57.14 \%)$ & $\mathrm{ns}$ \\
\hline$T T$ & $1(12.50 \%)$ & $1(6.67 \%)$ & $2(9.09 \%)$ & ns & $5(9.62 \%)$ & $4(10.81 \%)$ & $0(0.00 \%)$ & $\mathrm{ns}$ \\
\hline$G T+T T$ & $6(75 \%)$ & $10(66.67 \%)$ & $10(45.45 \%)$ & ns & $24(46.16 \%)$ & $19(51.35 \%)$ & $4(57.14 \%)$ & ns \\
\hline
\end{tabular}

with non-normal distribution. If variances of compared subgroups were heterogenous, Welch's ANOVA was used. Statistical analysis was performed using SPSS software (version 15.0).

\section{Results}

In the group of PA patients, $30(59.57 \%)$ were diagnosed to have a MS, and among the control group 8 subjects $(8.89 \%)$ fulfilled the criteria of MS.

PA patients had significantly higher BMI in comparison with the control group $(p<0.0001)$, and they also had significantly higher blood glucose levels $(\mathrm{p}=0.01)$ and TGs as well $(\mathrm{p}=0.0005)$. There were no significant differences in serum cholesterol levels among both groups (Table 1).

Frequencies of genotypes and alleles in patients and controls are shown in Table 2.

There were no significant differences in the prevalence of the $\mathrm{TT}$, TG, and GG genotypes of the T45G adiponectin gene polymorphism between both groups. In addition, there were no significant differences in the prevalence of the GG, GT, and TT genotypes of the G276T adiponectin gene polymorphism between PA and control groups.

There were no significant differences in the BMI 
Table 5. Genotypes and alleles frequencies depending on cholesterol and TAG values in PA patients.

\begin{tabular}{|c|c|c|c|c|c|c|}
\hline Patients & $\begin{array}{l}\text { Cholesterol } \\
\leq 5.2(\mathrm{n}=35)\end{array}$ & $\begin{array}{l}\text { Cholesterol } \\
>5.2(n=12)\end{array}$ & Significance & $\begin{array}{l}\text { Triglycerides } \\
\leq 1.2(\mathrm{n}=18)\end{array}$ & $\begin{array}{l}\text { Triglycerides } \\
>1.2(\mathrm{n}=29)\end{array}$ & Significance \\
\hline \multicolumn{7}{|l|}{$T 45 G$} \\
\hline T alleles & $63(95.00 \%)$ & $21(88 \%)$ & & $32(94 \%)$ & $52(93 \%)$ & \\
\hline$G$ alleles & $3(5 \%)$ & $3(13 \%)$ & ns & $2(6 \%)$ & $4(7 \%)$ & $\mathrm{ns}$ \\
\hline$T T$ & $30(90.91 \%)$ & $9(75.00 \%)$ & $\mathrm{ns}$ & $15(88.24 \%)$ & $24(85.71 \%)$ & $\mathrm{ns}$ \\
\hline$T G+G G$ & $3(9.09 \%)$ & $3(25.00 \%)$ & $\mathrm{ns}$ & $2(11.76 \%)$ & $4(14.29 \%)$ & $\mathrm{ns}$ \\
\hline \multicolumn{7}{|l|}{$G 276 T$} \\
\hline$G$ alleles & $45(64 \%)$ & $19(79 \%)$ & & $21(58 \%)$ & $43(74 \%)$ & \\
\hline T alleles & $25(36 \%)$ & $5(21 \%)$ & & $15(42 \%)$ & $15(26 \%)$ & \\
\hline$G G$ & $13(37.14 \%)$ & $8(66.67 \%)$ & 0.07 & $4(22.22 \%)$ & $17(58.62 \%)$ & 0.01 \\
\hline$G T$ & $19(54.29 \%)$ & $3(25.00 \%)$ & 0.08 & $13(72.22 \%)$ & $9(31.03 \%)$ & 0.006 \\
\hline$T T$ & $3(8.57 \%)$ & $1(8.33 \%)$ & ns & $1(5.56 \%)$ & $3(10.34 \%)$ & ns \\
\hline$G T+T T$ & $22(62.86 \%)$ & $4(33.33 \%)$ & 0.08 & $14(77.78 \%)$ & $12(41.37 \%)$ & 0.015 \\
\hline
\end{tabular}

and metabolic parameters in PA patients and controls according to the genotypes of the $\mathrm{T} 45 \mathrm{G}$ adiponectin gene polymorphism (Table 3 ).

Moreover, there were no significant differences in BMI and biochemical metabolic parameters between PA patients and controls with the 276GG genotype and the 276GT+TT genotypes (Table 3).

We also were not able to detect the significant differences in the prevalence of alleles and genotypes in patients and controls in relation to BMI, patients with normal weight had similar frequencies of alleles and genotypes as compared with overweight and obese patients and control subjects (Table 4).

However, patients with PA and higher TG had a significantly higher frequency of the GG genotype of the G276T polymorphism ( $\mathrm{p}=0.01$ ), and those with lower TG levels had a higher frequency of GT+TT $(\mathrm{p}=0.015)$. A similar tendency was observed also in relation to cholesterol levels; however the differences in the frequency of the GG and GT genotypes did not reach statistical significance (Table 5).

\section{Discussion}

Our present study confirmed a significantly higher prevalence of metabolic symptoms in PA patients compared to controls selected from general population matched for age and BMI. Moreover, we did not find significant differences in the distribution of genotypes and alleles of both T45G and G276T polymorphisms of the adiponectin gene. This study also demonstrated that
GG genotype of the G276T ADIPOQ gene polymorphism may be responsible for a worse metabolic profile in patients with PA.

The underlying mechanisms of the development of metabolic complications in PA patients have not been completely clarified, but the role of aldosterone overproduction seems to be crucial. The adipocyte mineralocorticoid receptors may mediate the proadipogenic effect of both aldosterone (EhrhartBornstein et al. 2004) and glucocorticoids (Krug and Ehrhart-Bornstein 2008) and, on the other hand, adipocytokine and lipid release from adipose tissue seems to be involved in the regulation of aldosterone secretion (Jang et al. 2005). Our study is consistent with previous findings demonstrating a higher prevalence of metabolic abnormalities in PA compared to controls.

We also assessed whether adiponectin gene polymorphisms can contribute to worse metabolic parameters in PA patients; unfortunately we did not find significant differences in the distribution of genotypes and alleles of the T45G and G276T ADIPOQ gene SNPs in patients and controls. This finding is not consistent with the study of Ronconi et al. (2010), they observed a significantly different distribution for the SNP G276T between PA patients and EH. In contrast to their study we compared PA patients with the general population, not subjects with EH.

We did not find significant differences in BMI or plasma levels of glucose, cholesterol, and TGs among different genotypes of the T45G and G276T adiponectin gene polymorphisms in PA patients and controls. 
However, the 276GG genotype in PA patients was linked to higher TG levels and a significantly higher frequency of 276GT+TT genotypes in patients was related to normal levels of TG. We observed a similar tendency also in relation to cholesterol level, however the differences in the frequency of the GG and GT genotypes did not reach statistical significance. Ronconi et al. (2010) reported a better metabolic profile in patients with the 276GG and GT genotypes compared to patients with the 276TT genotype. They also observed an association between the $45 \mathrm{GG}+\mathrm{TG}$ genotypes and a better metabolic profile and suggested a protective role of the $45 \mathrm{G}$ allele against central obesity and insulin resistance in PA patients; however we were not able to document this relationship in an East Slovak population with PA. We did not evaluate differences in lipid profile and genotypes between APA and IHA, but it could be a topic of interest in the future, because metabolic differences and differences in frequency of end-organ damage were demonstrated between patients with IHA and APA in a recent study (Šomlóová et al. 2012).

In the current literature, the results of studies on the ADIPOQ gene G276T and T45G polymorphisms and their association with MS are controversial. The $\mathrm{G}$ allele of the G276T polymorphism was associated with lower insulin sensitivity, lower levels of adiponectin, and increased levels of blood lipids (Hara et al. 2002, Gonzalez-Sanchez et al. 2005), and the $\mathrm{T}$ allele was found in subjects with higher levels of adiponectin and lower BMI (Menzaghi et al. 2004, Kyriakou et al. 2008). By contrast, two studies (Beebe-Dimmer et al. 2010, Huang et al. 2010) reported an association of the G276T $\mathrm{T}$ allele with obesity. Association of the adipokine genes with obesity-related metabolic disease has been explained by Enns et al. (2011). Authors concluded that the magnitude of change in adiponectin levels varies considerably between studies, since these studies examined populations very different in ethnicity, age, and health condition. Conversely, several studies did not find any association of the G276T SNP with metabolic disorders, obesity, or adiponectin levels (Iwashima et al. 2004, Lee et al. 2005, Vozarova de Courten et al. 2005), which is particularly in agreement with our study.

The G allele in T45G SNP is strongly associated with lower adiponectin levels, higher BMI, lower insulin sensitivity, higher risk of T2DM, and dyslipidemia, which is in part in agreement with our study.
Unfortunately we did not observe any association of the T45G SNP of the ADIPOQ gene with metabolic disturbance. However, we did not examine the plasma adiponectin levels, which is the main limitation of this study. On the other side adiponectin level in majority of studies was not related to above mentioned allele and genotypes of the $\mathrm{T} 45 \mathrm{G}$ and G276T polymorphisms. Moreover, the plasma levels of adiponectin may vary in various conditions, therefore plasma adiponectin evaluation did not seem to be crucial in relation to these polymorphisms. In several studies the relationship between $\mathrm{T} 45 \mathrm{G}$ and G276T adiponectin gene polymorphisms and serum adiponectin levels was not observed (Demirci et al. 2010, Al-Daghri et al. 2012, Tsuzaki et al. 2012). In our study we focused especially on metabolic symptoms as a part of MS. Second limitation of the study is a relatively small group of patients with PA and a different gender distribution between controls and patients, although to our best knowledge this is the second largest study regarding the T45G and G276T adiponectin gene polymorphisms in PA patients.

In conclusion, our results document a higher prevalence of some metabolic disturbances in patients with PA compared to an age-matched control group, at least partially due to aldosterone overproduction. There are no significant differences in the genotypes and allele distribution of the G276T and T45G SNPs of the adiponectin gene among PA patients and controls in an East Slovakian population. In PA patients with normal TG levels we observed a higher frequency of the 276GT genotype and a lower frequency of the $276 \mathrm{GG}$ genotype, indicating that the $\mathrm{T}$ allele may be protective for the development of hyperlipidemia in primary aldosteronism. However, this association needs to be confirmed by studies on larger cohorts of subjects.

\section{Conflict of Interest}

There is no conflict of interest.

\section{Acknowledgements}

This work was supported by the Agency of the Ministry of Education of the Slovak Republic for the Structural funds of the European Union, Operational Programme Research and Development Contract no. 005/2009/2.1/OPR\&D $50 \%$ and Ministry of Healthcare of the Slovak Republic (MZ 2007/ 4 - UPJS-1) $50 \%$. 


\section{References}

AL-DAGHRI NM, AL-ATTAS OS, ALOKAIL MS, ALKHARFY KM, HUSSAIN T, YAKOUT S, VINODSON B, SABICO S: Adiponectin gene polymorphisms (T45G and G276T), adiponectin levels and risk for metabolic diseases in an Arab population. Gene 493: 142-147, 2012.

BEEBE-DIMMER JL, ZUHLKE KA, RAY AM, LANGE EM, COONEY KA: Genetic variation in adiponectin (ADIPOQ) and the type 1 receptor (ADIPOR1), obesity and prostate cancer in African Americans. Prostate Cancer Prostatic Dis 13: 362-368, 2010.

BOSCARO M, RONCONI V, TURCHI F, GIACCHETTI G: Diagnosis and management of primary aldosteronism. Curr Opin Endocrinol Diabetes Obes 15: 332-338, 2008.

CUSPIDI C, MEANI S, FUSI V, SEVERGNINI B, VALERIO C, CATINI E, LEONETTI G, MAGRINI F, ZANCHETTI A: Metabolic syndrome and target organ damage in untreated essential hypertensives. J Hypertens 22: 1991-1998, 2004.

DEMIRCI H, YILMAZ M, ERGUN MA, YURTCU E, BUKAN N, AYVAZ G: Frequency of adiponectin gene polymorphisms in polycystic ovary syndrome and the association with serum adiponectin, androgen levels, insulin resistance and clinical parameters. Gynecol Endocrinol 26: 348-355, 2010.

EHRHART-BORNSTEIN M, ARAKELYAN K, KRUG AW, SCHERBAUM WA, BORNSTEIN SR: Fat cells may be the obesity-hypertension link: human adipogenic factors stimulate aldosterone secretion from adrenocortical cells. Endocr Res 30: 865-870, 2004.

ENNS JE, TAYLOR CG, ZAHRADKA P: Variations in adipokine genes AdipoQ, Lep, and LepR are associated with risk for obesity-related metabolic disease: the modulatory role of gene-nutrient interactions. $J$ Obes 2011 : 168659, 2011.

EXECUTIVE SUMMARY of the Third Report of the National Cholesterol Education Program (NCEP) Expert Panel on Detection, Evaluation, and Treatment of High Blood Cholesterol in Adults (Adult Treatment Panel III). JAMA 285: 2486-2497, 2001.

FALLO F, VEGLIO F, BERTELLO C, SONINO N, DELLA MEA P, ERMANI M, RABBIA F, FEDERSPIL G, MULATERO P: Prevalence and characteristics of the metabolic syndrome in primary aldosteronism. $J$ Clin Endocrinol Metab 91: 454-459, 2006.

FUNDER JW, CAREY RM, FARDELLA C, GOMEZ-SANCHEZ CE, MANTERO F, STOWASSER M, YOUNG WF, MONTORI VM: Case detection, diagnosis, and treatment of patients with primary aldosteronism: an endocrine society clinical practice guideline. J Clin Endocrinol Metab 93: 3266-3281, 2008.

GONZALEZ-SANCHEZ JL, ZABENA CA, MARTINEZ-LARRAD MT, FERNANDEZ-PEREZ C, PEREZ-BARBA M, LAAKSO M, SERRANO-RIOS M: An SNP in the adiponectin gene is associated with decreased serum adiponectin levels and risk for impaired glucose tolerance. Obes Res 13: 807-812, 2005.

HANNEMANN A, WALLASCHOFSKI H: Prevalence of primary aldosteronism in patient's cohorts and in populationbased studies-a review of the current literature. Horm Metab Res 44: 157-162, 2012.

HARA K, BOUTIN P, MORI Y, TOBE K, DINA C, YASUDA K, YAMAUCHI T, OTABE S, OKADA T, ETO K, KADOWAKI H, HAGURA R, AKANUMA Y, YAZAKI Y, NAGAI R, TANIYAMA M, MATSUBARA K, YODA M, NAKANO Y, TOMITA M, KIMURA S, ITO C, FROGUEL P, KADOWAKI T: Genetic variation in the gene encoding adiponectin is associated with an increased risk of type 2 diabetes in the Japanese population. Diabetes 51: 536-540, 2002.

HUANG MC, WANG TN, LEE KT, WU YJ, TU HP, LIU CS, CHIANG HC, KO YC: Adiponectin gene SNP276 variants and central obesity confer risks for hyperglycemia in indigenous Taiwanese. Kaohsiung J Med Sci 26: 227-236, 2010.

IACOBELliS G, PETRAMALA L, COTESTA D, PERGOLINI M, ZINNAMOSCA L, CIANCI R, De TOMA G, SCIOMER S, LETIZIA C: Adipokines and cardiometabolic profile in primary hyperaldosteronism. $J$ Clin Endocrinol Metab 95: 2391-2398, 2010.

INADERA H: The usefulness of circulating adipokine levels for the assessment of obesity-related health problems. Int $J$ Med Sci 5: 248-262, 2008. 
IWASHIMA Y, KATSUYA T, ISHIKAWA K, OUCHI N, OHISHI M, SUGIMOTO K, FU Y, MOTONE M, YAMAMOTO K, MATSUO A, OHASHI K, KIHARA S, FUNAHASHI T, RAKUGI H, MATSUZAWA Y, OGIHARA T: Hypoadiponectinemia is an independent risk factor for hypertension. Hypertension 43: 1318$1323,2004$.

JANG Y, LEE JH, CHAE JS, KIM OY, KOH SJ, KIM JY, CHO H, LEE JE, ORDOVAS JM: Association of the $276 \mathrm{G}->\mathrm{T}$ polymorphism of the adiponectin gene with cardiovascular disease risk factors in nondiabetic Koreans. Am J Clin Nutr 82: 760-767, 2005.

KRUG AW, EHRHART-BORNSTEIN M: Adrenocortical dysfunction in obesity and the metabolic syndrome. Horm Metab Res 40: 515-517, 2008.

KYRIAKOU T, COLLINS LJ, SPENCER-JONES NJ, MALCOLM C, WANG X, SNIEDER H, SWAMINATHAN R, BURLING KA, HART DJ, SPECTOR TD, O'DELL SD: Adiponectin gene ADIPOQ SNP associations with serum adiponectin in two female populations and effects of SNPs on promoter activity. J Hum Genet 53: 718 $727,2008$.

LEE YY, LEE NS, CHO YM, MOON MK, JUNG HS, PARK YJ, PARK HJ, YOUN BS, LEE HK, PARK KS, SHIN HD: Genetic association study of adiponectin polymorphisms with risk of Type 2 diabetes mellitus in Korean population. Diabet Med 22: 569-575, 2005.

LI S, SHIN HJ, DING EL, VAN DAM RM: Adiponectin levels and risk of type 2 diabetes: a systematic review and meta-analysis. JAMA 302: 179-188, 2009.

MENZAGHI C, ERCOLINO T, SALVEMINI L, COCO A, KIM SH, FINI G, DORIA A, TRISCHITTA V: Multigenic control of serum adiponectin levels: evidence for a role of the APM1 gene and a locus on 14q13. Physiol Genomics 19: 170-174, 2004.

MENZAGHI C, TRISCHITTA V, DORIA A: Genetic influences of adiponectin on insulin resistance, type 2 diabetes, and cardiovascular disease. Diabetes 56: 1198-1209, 2007.

MOUSAVINASAB F, TAHTINEN T, JOKELAINEN J, KOSKELA P, VANHALA M, OIKARINEN J, KEINANENKIUKAANNIEMI S, LAAKSO M: Common polymorphisms (single-nucleotide polymorphisms SNP+45 and $\mathrm{SNP}+276$ ) of the adiponectin gene regulate serum adiponectin concentrations and blood pressure in young Finnish men. Mol Genet Metab 87: 147-151, 2006.

MTIRAOUI N, EZZIDI I, TURKI A, CHAIEB A, MAHJOUB T, ALMAWI WY: Single-nucleotide polymorphisms and haplotypes in the adiponectin gene contribute to the genetic risk for type 2 diabetes in Tunisian Arabs. Diabetes Res Clin Pract 97: 290-297, 2012.

OHASHI K, OUCHI N, MATSUZAWA Y: Anti-inflammatory and anti-atherogenic properties of adiponectin. Biochimie 94: 2137-2142, 2012.

RONCONI V, TURCHI F, RILLI S, Di MATTIA D, AGOSTINELLI L, BOSCARO M, GIACCHETTI G: Metabolic syndrome in primary aldosteronism and essential hypertension: relationship to adiponectin gene variants. Nutr Metab Cardiovasc Dis 20: 93-100, 2010.

ROSSI GP: Prevalence and diagnosis of primary aldosteronism. Curr Hypertens Rep 12: 342-348, 2010.

SCHWARZ PE, GOVINDARAJALU S, TOWERS W, SCHWANEBECK U, FISCHER S, VASSEUR F, BORNSTEIN SR, SCHULZE J: Haplotypes in the promoter region of the ADIPOQ gene are associated with increased diabetes risk in a German Caucasian population. Horm Metab Res 38: 447-451, 2006.

ŠOMLÓOVÁ Z, INDRA T, ROSA J, PETRÁK O, ŠTRAUCH B, ZELINKA T, HOLAJ R, WIDIMSKÝ J JR: Have main types of primary aldosteronism different phenotype? Physiol Res 61: 431-436, 2012.

TSUZAKI K, KOTANI K, SANO Y, FUJIWARA S, GAZI IF, ELISAF M, SAKANE N: The relationship between adiponectin, an adiponectin gene polymorphism, and high-density lipoprotein particle size: from the Mima study. Metabolism 61: 17-21, 2012.

TURER AT, SCHERER PE: Adiponectin: mechanistic insights and clinical implications. Diabetologia 55: 2319-2326, 2012.

VOZAROVA DE COURTEN B, HANSON RL, FUNAHASHI T, LINDSAY RS, MATSUZAWA Y, TANAKA S, THAMEEM F, GRUBER JD, FROGUEL P, WOLFORD JK: Common polymorphisms in the adiponectin gene ACDC are not associated with diabetes in Pima Indians. Diabetes 54: 284-289, 2005.

WEYER C, FUNAHASHI T, TANAKA S, HOTTA K, MATSUZAWA Y, PRATLEY RE, TATARANNI PA: Hypoadiponectinemia in obesity and type 2 diabetes: close association with insulin resistance and hyperinsulinemia. J Clin Endocrinol Metab 86: 1930-1935, 2001. 